Brit. F. vener. Dis. (1971) 47, 198

\title{
Transport of herpes simplex virus in Stuart's medium
}

\author{
P. RODIN, M. J. HARE, C. F. BARWELL, AND M. J. WITHERS
}

From the Departments of Venereology and Bacteriology, The London Hospital

Infection of the genitalia with herpes simplex virus has attracted considerable interest in recent years, especially in its possible relationship with carcinoma of the cervix (Josey, Nahmias, and Naib, 1968). In Great Britain it is the commonest cause of erosive lesions on the genitalia.

It is generally recommended that swabs for herpes culture should reach the laboratory within a short time, but this is difficult if there is no virus laboratory nearby. In venereal disease clinics, in particular, patients may be seen at times when the laboratory has ceased work for the day and specimens will have to be kept overnight or even over the weekend. Stuart's transport medium (Stuart, 1946; Moffett, Young, and Stuart, 1948; Stuart, 1956) is well known as a suitable transport medium for many bacteria (Gästrin, Kallings, ard Marcetic, 1968) and is widely used in venereal disease clinics for transporting swabs to be cultured for gonococci. To our knowledge, however, it has not been tested as a transport medium for viruses.

Initially a pilot study was made to assess the efficacy of transporting swabs in Stuart's transport medium (STM) compared with plain swabs. Subsequently swabs placed in STM were compared with swabs placed in a virus transport medium (VTM).

\section{Material and methods}

For the purpose of this study only those cases are considered in which herpes virus was grown in at least one of the paired specimens taken. In the initial series, altogether 24 pairs of swabs were taken from the penis, vulva, or cervix of seventeen patients (twelve women and five men) and on the basis of serological evidence eight were thought to have primary infections. In the later series, comparing STM with VTM, 54 pairs of swabs were obtained from 34 patients (27 men and seven women), and seven were considered to have primary infections. Most of the swabs used contained charcoal as recommended for transporting specimens of gonococci (Moffett and others, 1948).

The VTM consisted of Eagle's tissue culture medium containing 10 per cent. foetal calf serum and $200 \mu \mathrm{g} . / \mathrm{ml}$. penicillin, $100 \mu \mathrm{g} . / \mathrm{ml}$. streptomycin, and $50 \mu \mathrm{g} . / \mathrm{ml}$. mycostatin. It was put into bijou bottles in 5-ml. amounts.

The STM was obtained from the V.D. Reference Laboratory, Ashfield Street, London, E.1, and was prepared according to Stuart's original formula (Stuart, 1946).

Swabs reaching the virus laboratory in VTM were squeezed out in the VTM (VTM extract). Swabs in STM were squeezed out in $1.5 \mathrm{ml}$. of Eagle's maintenance medium (STM extract).

HeLa cells were inoculated as follows:

\section{VTM EXTRACT}

Three culture tubes had their $1.0 \mathrm{ml}$. of maintenanceco medium replaced with $1.0 \mathrm{ml}$. of extract. Neutralizing? serum was included in one of these tubes. A fourth tube was included as a cell control.

\section{STM EXTRACT}

$0.2 \mathrm{ml}$. was added to three tubes, one of which contained neutralizing serum. A fourth tube was included as a cell control.

All tubes were incubated at $33^{\circ} \mathrm{C}$. in a roller drum apparatus. If Candida grew in specimens which had been sent in STM, mycostatin was later added to the culture tubes with satisfactory results. Identification of a cytopathic effect as due to herpes simplex was given by the neutralizing serum. The majority of positive specimens showed within 5 days but tubes were kept for up to 12 days.

\section{Results}

Table I compares the results for the plain swabs and those placed in STM.

TABLE I Comparison of results with plain swabs and swabs in Stuart's transport medium (STM)

\begin{tabular}{|c|c|c|c|}
\hline \multirow{2}{*}{ Swabs used } & \multicolumn{2}{|l|}{ Results } & \multirow{2}{*}{ Total } \\
\hline & Immediate & Delayed (1-2 days) & \\
\hline $\begin{array}{l}\mathbf{P}+\mathbf{S T M}+ \\
\mathbf{P}+\text { STM - } \\
\mathbf{P}-\mathbf{S T M}+ \\
\mathbf{P}-\mathrm{STM}-\end{array}$ & $\begin{array}{r}13 \\
2 \\
2 \\
0\end{array}$ & $\begin{array}{l}2 \\
0 \\
4 \\
1\end{array}$ & $\begin{array}{r}15 \\
2 \\
6 \\
1\end{array}$ \\
\hline Total & 17 & 7 & 24 \\
\hline
\end{tabular}

$\mathbf{P}=$ plain swab 
When specimens were taken immediately to the laboratory, each method was positive in fifteen out of seventeen instances but the delayed specimens were positive in only two out of seven of the plain swabs compared with six out of seven in STM.

Table II compares the results for VTM with those using STM.

TABLE II Comparison of results with virus and Stuart's transport medium

\begin{tabular}{|c|c|c|c|c|c|c|c|}
\hline \multirow{3}{*}{ Medium } & \multicolumn{6}{|l|}{ Results } & \multirow{3}{*}{ Total } \\
\hline & \multirow[t]{2}{*}{ Immediate } & \multicolumn{5}{|c|}{ Delayed (no. of days) } & \\
\hline & & 1 & 2 & 3 & 4 & 5 & \\
\hline $\begin{array}{l}\text { VTM + STM + } \\
\text { VTM + STM - } \\
\text { VTM - STM + } \\
\text { VTM - STM - }\end{array}$ & $\begin{array}{r}17 \\
5 \\
1 \\
0\end{array}$ & $\begin{array}{r}11 \\
0 \\
0 \\
1\end{array}$ & $\begin{array}{l}3 \\
0 \\
0 \\
0\end{array}$ & $\begin{array}{l}8 \\
1 \\
0 \\
0\end{array}$ & $\begin{array}{l}2 \\
1 \\
1 \\
1\end{array}$ & $\begin{array}{l}2 \\
0 \\
0 \\
0\end{array}$ & $\begin{array}{r}43 \\
7 \\
2 \\
2\end{array}$ \\
\hline Total & 23 & 12 & 3 & 9 & 5 & 2 & 54 \\
\hline
\end{tabular}

Those specimens in VTM taken immediately to the laboratory were positive in 22 out of 23 cases compared with eighteen out of 23 in STM. Although VTM seemed slightly better with the immediate specimens the delayed specimens showed almost identical results with the two media, namely 28 out of 31 positive with VTM and 27 out of 31 with STM.

Of a total of 42 delayed specimens kept at $4^{\circ} \mathrm{C}$. before processing two were negative compared with two out of twenty kept at room temperature.

Forty delayed specimens (twenty VTM and twenty STM) were sent, in cases from which earlier specimens had also been taken. In four instances the delayed culture was negative when the initial one was positive; two were kept in VTM and two in STM, one of each having been kept at room temperature. In one case the specimen in STM was positive after a delay of 3 days at room temperature when the immediate specimen had been negative. With VTM there were no positives in the delayed specimens when the immediate specimen had been negative.

\section{Conclusions}

Where a virus laboratory is available on the spot, a plain swab may be sent for herpes culture. If delay is involved, either VTM or STM should be used and it is not essential to keep the specimens refrigerated. STM has the advantage that it does not contain any antibiotics and can also be used for transporting swabs for bacterial examination, especially for the gonococcus. In venereal disease and gynaecological clinics, where tests for herpes virus and gonococci are most likely to be taken, STM would serve as a suitable transport medium for both organisms.

We have not attempted to transport other viruses in STM, but this might be worth evaluating. It also suggests itself as a possible transport medium for Bedsonia (Chlamydia).

\section{Summary}

Stuart's transport medium is compared with a plain swab and a virus transport medium for transporting specimens from genital lesions for herpes virus culture. Stuart's medium proved satisfactory and can be used in cases in which the arrival of the specimen at the laboratory may be delayed. For general use it has the advantage over virus transport mediumb that it is also suitable for transporting bacteria.

\section{References}

Gästrin, B., Kallings, L. O., and Marcetic, A. (1968) Acta path. microbiol. scand., 74, 371

Josey, W. E., Nahmias, A. J., and NaIb, Z. M. (1968) Amer. F. Obstet. Gynec., 101, 718

Moffett, M., Young, J. L., and Stuart, R. D. (1948) Brit. med. F., 2, 421

STUART, R. D. (1946) Glasg. med. F., 27, 131

- (1956) Canad. F. publ. Hlth, 47, 114

Transport du virus de l'herpès simplex dans le milieu de Stuart

\section{SOMMAIRE}

Pour la culture du virus de l'herpès, on a comparé le milieu de transport de Stuart avec l'écouvillon habituel et un milieu de transport pour virus dans une étude de transport de specimens, à partir de lésions génitales. Le milieu de Stuart s'est montré satisfaisant et il peut être utilisé dans les cas où l'arrivée du specimen de laboratoire se trouve être retardée. En pratique courante, il a l'avantage sur un milieu de transport pour virus dans le fait qu'il convient également pour le transport des bactéries. 